A Journal of Culture, English Language, Teaching \& Literature ISSN 1414-3320 (Print), ISSN 2502-4914 (Online)

Vol. 20 No.1; June 2020

Copyright (@) Soegijapranata Catholic University, Indonesia

Identifying Cultural Values of the Narrative Texts in an English Textbook for Tenth Grade of Senior High School

${ }^{1}$ Urip Sulistiyo, ${ }^{2}$ Kaspul Anwar, ${ }^{3}$ Gemila Lestari, ${ }^{4}$ Desi Afriani, ${ }^{5}$ Widya Kartika, and ${ }^{6}$ Retno Wulan

1,3,4,5,6English Education Department, Universitas Jambi, Indonesia

${ }^{2}$ STAI Ahsanta Jambi, STAI Ahsanta Jambi, Center for Scientific Publication,

Universitas Jambi, Indonesia

email: ${ }^{1}$ urip.sulistiyo@unja.ac.id; ${ }^{2}$ kaspulanwar.as@gmail.com; gemilalestari96@gmail.com; ${ }^{4}$ dafriani@yahoo.com; 5hayyanmikhail@gmail.com; ${ }^{6}$ renowulan268@gmail.com

Received: 28-12-2019

Accepted: 02-01-2020

Published: 04-06-2020 


\title{
Identifying Cultural Values of the Narrative Texts in an English Textbook for Tenth Grade of Senior High School
}

\author{
${ }^{1}$ Urip Sulistiyo, ${ }^{2}$ Kaspul Anwar, ${ }^{3}$ Gemila Lestari, ${ }^{4}$ Desi Afriani, \\ ${ }^{5}$ Widya Kartika, and ${ }^{6}$ Retno Wulan \\ 1urip.sulistiyo@unja.ac.id; ${ }^{2}$ kaspulanwar.as@gmail.com; \\ 33emilalestari96@gmail.com; ${ }^{4}$ dafriani@yahoo.com; \\ 5hayyanmikhail@gmail.com; ${ }^{6}$ renowulan268@gmail.com
}

${ }^{1,3,4,5,6}$ English Education Department, Universitas Jambi, Indonesia

${ }^{2}$ STAI Ahsanta Jambi, STAI Ahsanta Jambi, Center for Scientific Publication, Universitas Jambi, Indonesia

\begin{abstract}
Many English teachers assumed that culture cannot be separated from English learning. This paper aimed to investigate the cultural values of the narrative texts in the English textbook for grade tenth of senior high school. The data of the research were collected from the narrative reading passage in an English textbook for senior high school entitled "Bahasa Inggris", English textbook Curriculum 2013 (henceforth, K13) published by The Ministry of Education of Republic of Indonesia. To reveal what culture values represented in the narrative reading passage in the textbook, the cultural values were categorized into several source cultures such as the visual representation of the cultures, and the objectives of the lesson related to cultural values in narrative texts. Moreover, the findings of this research discovered that there were three cultural values identified in the narrative reading passages in the textbook such as respect for the right indigenous people, finding peace and nature and with all forms of life, and appreciation of cultural products.
\end{abstract}

Key words: Cultural values, English textbook, EFL, narrative text, qualitative 
Abstrak: Banyak guru bahasa Inggris berasumsi bahwa budaya tidak dapat dipisahkan dari pembelajaran bahasa Inggris. Artikel ini bertujuan untuk menyelidiki nilai-nilai budaya dari teks naratif dalam buku bacaam bahasa Inggris untuk kelas sepuluh Sekolah Menengah Atas. Data penelitian dikumpulkan dari teks naratif dalam buku bacaan bahasa Inggris untuk sekolah menengah atas yang berjudul "Bahasa Inggris", buku bacaan bahasa Inggris Kurikulum 2013 (K13) yang diterbitkan oleh Kementerian Pendidikan Republik Indonesia. Untuk mengungkapkan nilai-nilai budaya yang presentasikan dalam teks naratif dalam buku bacaan tersebut, nilai-nilai budaya dikategorikan ke dalam beberapa bagian, seperti representasi visual dari budaya, dan tujuan pelajaran terkait dengan nilai-nilai budaya dalam teks naratif. Lebih lanjut, temuan penelitian ini menemukan bahwa ada tiga nilai budaya yang teridentifikasi pada teks naratif dalam buku bacaan itu, seperti penghormatan terhadap budaya masyarakat lokal, bersahabat dengan alam dalam berbagai kegiatan kehidupan seharihari, dan penghargaan terhadap produk-produk budaya.

Kata kunci: Nilai-nilai budaya, buku bacaan Bahasa Inggris, EFL, teks naratif, kualitatif

\section{INTRODUCTION}

Generally, learning English refers to the ability of both written and spoken communication using English well. It implies that the English classroom does not only enable students to convey their message but also to comprehend the meaning beyond its context. Hence, the information should not only cover the language features but also its context, also known as the culture within. According to Lestari (2010), cultural contexts in language learning are very important to stimulate cultural understanding enabling them to have intercultural communication. Therefore, an English classroom ought to integrate the language course to cultural learning.

In line with the statement above, the purpose of Indonesian national education is to perform a classroom-based on national cultural values and ideologies while integrating them into all subjects including English as the international subject (Kim \& Paek, 2015). The integration could be conducted by learning materials in the classroom such as textbooks. Considering that the textbook plays an important role in the 
English classroom, the contents ought to be taken into consideration as well. According to Fernandez (2011), the process of selecting the textbooks in Indonesian education varies including the financial factors and visual appearance of textbooks. On the other hand, the tendency of textbooks chosen is often inappropriate in terms of its cultural contents. Sometimes, the government gives unreliable English textbooks and they are not appropriate to Indonesian students' needs in learning English (Setyono \& Widodo, 2019).

Moreover, English is the medium to communicate in international and intercultural contexts requiring people in particular, the students to use it in their real circumstances or environment (Kim \& Paek, 2015). In addition, the Indonesian teachers closely relied on their textbook to derive the teaching and learning processes in the classroom, not limited to the English learning. They value the textbook as an instrument playing an important role in language teaching and learning. Thus, most of the Indonesian teachers put the textbooks as the core materials of language teaching.

Since a couple of years ago, the Indonesian Ministry of Education had proposed that the aim of English education should be revised not only to assist the learners to speak like native speakers of English but to be able to understand the intercultural of the speakers. To reach this objective, the current curriculum has taken such contents into account that it includes the multicultural aspects as well as the local or Indonesian culture (Setyono \& Widodo, 2019). In this case, the sets of cultural values described in Indonesian English textbooks have brought the hidden curriculum to the classroom. The curriculum might influence learners' perceptions of the cultural values and elements delivered for their participation in the classroom (Kim \& Paek, 2015).

Even though the representation of cultural values and contents has serious impacts on learners' point of views towards the cultural information regarding how they value the culture and its other element, few researchers have discussed the issues, especially in the Indonesian context. Therefore, this study will critically analyze the cultural values in each narrative text presented in an English textbook of the tenth grade of Senior high school. 
Volume 20, Number 1, June 2020, pp. 59 - 72

\section{LITERATURE REVIEW}

\section{A. Narrative Text Definition}

Narrative text aims at telling the stories to the readers. It consists of the characters, setting, plot, conflict, and resolution as the ending of the story. "Narrative Fiction is organized around issues such as events, time, focalization, characterization, narration, the text, and its reading rather than individual theorists or approaches" (Kenan, 2003, p.1). In addition, such text identically contains moral values as implied meaning and lessons learned at the end of the story. Each character usually plays an important side leading to the whole story and its conflict in particular that every reader can engage in the sequence of each part of the story. Based on Toolan, (2012) a narrative is a perceived sequence of non-randomly connected events, typically involving, as the experiencing agonist, humans or quasi-humans, or other sentient beings, from whose experience we humans can 'learn'. From this definition we can see that: (1) it can be more than one foregrounded individual as experiencers, and (2) from the idea we can take 'learning' from narratives.

Moreover, Phillips (2017) stated that there are three characteristics features of narrative text. First, it consists of the characters, setting, plot, and conflict of the story. Second, it emphasizes to the plot of the event. Third, it is not only occurring in fiction (short story, romantic story, and novel) but also occurring in non-fiction such as history, newspaper, and true story. Besides, he also argued that there are two types of narrative text. First, the sequence of time also known as the chronology of the story indicated by "long time ago", "tomorrow", "yesterday", "at 09:00 pm", "later", and so on. Second, is the sequence of the event which emphasizes the plot of the story.

According to Linda \& Wignell (1994), there are three characteristics of narrative text consisting of social function, generic structure, and significant lexicon-grammatical features. The social function is dealing with an actual or demonstrating an experience in different ways, narratives text deal with the problematic event which leads to a turning point of some kind which in turn finds out the resolution. Besides, there are several components in the generic structure of a narrative text, such as orientation, evaluation, complication, resolution, and reorientation. Meanwhile, the significant lexicon-grammatical features focus on a specific 
point and usually individualized participant. Additionally, the features are the use of material processes like (and in this text, behavioral and verbal process) and use of relational process as well as the mental process in the story. Finally, the temporal conjunction, temporal circumstances, and past tense to describe the story are all the components of generic structures of the narrative text.

Based on some theories above, some narrative texts in the English textbook for senior high school are very acceptable because they all aim to entertain the readers through the story. Hence, the learning process will be effective if learners feel happy during the learning process. Thus, the objective of the study related to the syllabus will be achieved if the teaching and learning process becomes an effective activity in the classroom.

\section{B. Cultural Values in Narrative Reading Text}

Commonly, culture refers to the beliefs, customs, and everyday life of a particular ethnic, regional, or national group. It might also be used in speaking of a group that is not racially or ethnically based. Sometimes these labels can cause more harm than good when they are used to separate people into artificial categories.

Cultural values may create a challenge in interpreting texts, especially when the author and readers are from two different cultures. An example of clashing cultural values that one might encounter while reading literature is connected to the value of the words themselves. Tang (2006) asserts that Americans place great value on words as conveyers of fact while the Chinese put more emphasis on action. Chinese see the truth in the action, not necessarily the words. Thus, it is not enough to know the glosses for various words or even appropriate and inappropriate behaviors only; to understand the deep meaning of culture, intercultural readers must seek out a solid understanding of the cultural implications of those behaviors.

\section{Integrating Local Culture in English Language Teaching}

As Barfield and Uzarski (2009) claimed that "integrating local indigenous culture into English language learning not only educates learners about indigenous people in their own countries and throughout 
the world; it also makes learning English more relevant for indigenous students in those classrooms" (Barfield \& Uzarski, 2009). The behavior or someone's speech can be interpreted differently by listeners or interlocutors who come from different cultural backgrounds.

Another reason why cultural knowledge is necessary taught in language classes is the fact that culture is one element that is very exciting in language. The teacher should also introduce the language culture they teach (Dobson as cited in Lies and Lestari (2010). Thus, students will be motivated to learn because they do not only learn about language but also how it is used in real communication.

Based on the previous explanation, the researchers summarized that local culture is a culture that belongs to a region that describes the social conditions in the region. The integration of local culture into learning is very important as an effort to cultivate the values contained in local culture and at the same time to minimize the negative influence of external culture, especially the western culture brought by globalization. Incorporating the elements of culture in language learning, especially learning English or other languages, has teachers invite the students to respect the culture of either their local or other nations.

\section{The Use of Textbook in the English Language}

English textbooks are important as one of the aspects supporting the success of the learning process. This is in line with what was conveyed by the regulation of the Minister of National Education, No. 11 the year 2005 that lesson textbooks must be used by teachers and students as a reference in the learning process while the textbooks ought to comply with the national objective (Faris, 2014). Additionally, the regulation of Minister of National Education, No. 2 the year 2008 emphasized that textbooks for elementary, secondary and tertiary education, referred to as textbooks, are mandatory reference books to be used in primary, secondary and tertiary education units that contain material to increase devotion, faith, truthfulness, and personality, mastery of science and technology, increased sensitivity and aesthetic abilities, improvement of kinaesthetic and health abilities compiled based on national education standards.

Textbooks are a key component in most language programs. They serve as the basis for much of the language input and practice in the 
classroom. They may provide the basis for the content of the lessons, the balance of skills taught, and the kinds of language practice the students take part in. In other situations, the textbook may serve primarily to supplement the teacher's instruction. Rahmawati (2015) suggested that both teachers and school officers (librarians) should collaborate to develop an optimum quality of the textbook that students could access even in the libraries. Meanwhile, in terms of the learners, the textbook may provide the major source of contact they have with the language apart from an input provided by the teacher. In the case of inexperienced teachers, textbooks may also serve as a form of teacher training - they provide ideas on how to plan and teach lessons as well as formats that teachers can use. Much of the language teaching that occurs throughout the world today could not take place without the extensive use of commercial textbooks. Hence, teachers' professional knowledge should have been integrated into an understanding of how to implement and synchronize the textbooks into the classroom teaching (Ranjan, 2018).

Based on the explanation above, the researchers summarized that textbooks are books used in teaching and learning activities and arranged following the needs of students to achieve learning goals. Writing textbooks must refer to the curriculum and must be reflected in the existence of materials with different levels of depth and breadth between classes. The textbooks are published and disseminated to schools that are prepared by experts in their fields to support teaching programs outlined by the government which is appropriate and easily understood by the users in schools so that it supports a teaching program. On the other hand, Tüm \& Uguz (2014) stated that the impact of the culture on language teaching, learning, and performing was far more than just foods, fairs, folklores, and statistic facts. Further, it needed to link with both inter and intra-cultures not only to stand as the background but also connected to interpersonal understanding. Some cultural inputs should be included on cultural teaching in language teaching such as; social identity and group (social class, regional identity, and ethnic minorities), social interaction (differing level of formality as outsider and insider), belief and behavior ( moral, religious beliefs, and daily routines), socialization and the life cycle (families, schools, and rites of passage), national history (historical and contemporary events), stereotypes and national identity (what is "typical" symbol of national stereotypes). 


\section{METHOD}

This study aimed to find out the cultural values of the narrative reading texts in an English textbook for the tenth grade of senior high school students. Creswell (2012) stated that "qualitative research is a suitable design to address the research problems which we do not know the variables and need to investigate" (Creswell, 2012). Based on the problems and objectives of this research, the researchers used a descriptive qualitative approach to gain the data as it is a basic approach used in qualitative research design (Taurus, Hamizi \& Munjiatun, 2015). The researchers used this method to describe and analyse cultural values of narrative texts in English textbook for tenth grade students of senior high school level.

To gain rich data and information, the researchers relied on the literature technique. Firstly, the researchers collected the English textbook for grade tenth of senior high school that relevant to the research problems and selected the potential reading passage, particularly the narrative text which contains cultural values.

Moreover, the researchers conducted the data collection through five stages comprising of reading all the contents of the textbook that relevant to the problem of the research investigating, identifying the contents of the textbook, classifying the data appropriate with the purpose of the research, analyzing each narrative story provided in the textbook, and summarizing the research findings based on the data analysis.

\section{ANALYSIS AND DISCUSSION}

In this section, the researchers focused on cultural values represented in the narrative texts in an English textbook for grade tenth of senior high school and in what ways the English textbook provides EFL learners with opportunities to increase their understanding of intercultural knowledge and awareness. The author of the selected EFL textbook presented the cultural values through sets of visual representations.

Visually, folklore stories, pictures, photographs, and visual artifacts portrayed the cultural values that both teachers and students need to 
Sulistiyo, U., Anwar, K., Putri, D. H., Suskandani, N., Arini, A. P. \&

Wulan, R., Infusing Cultural Values in an English Textbook

realize, but these often go unnoticed. Uncovering these values in a textbook was intended to build and enhance both teachers' and students' awareness of the cultural values represented in the textbook.

Table 1:

The representation of cultural values in the textbook, Bahasa Inggris for Senior High School Grade X.

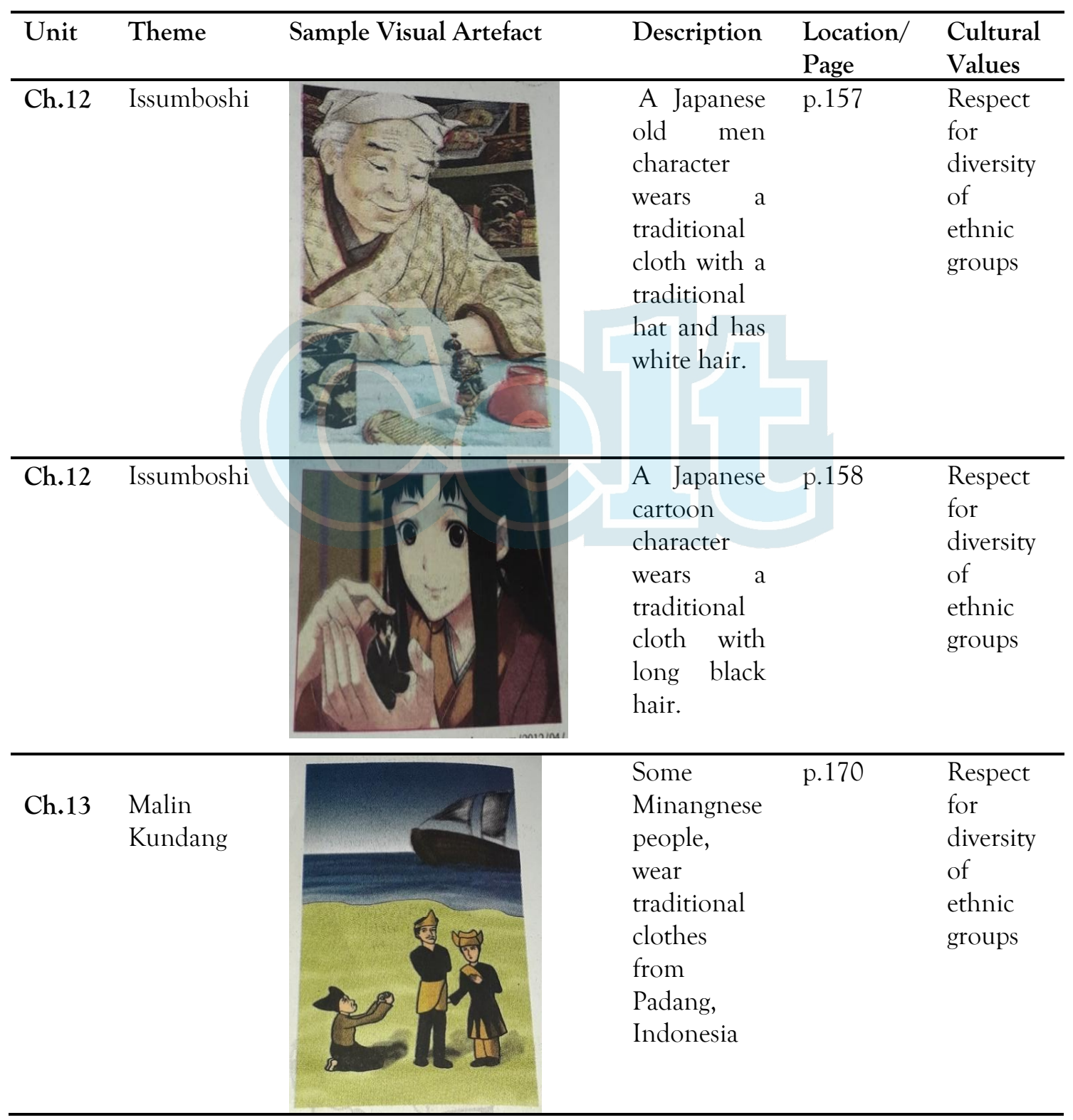




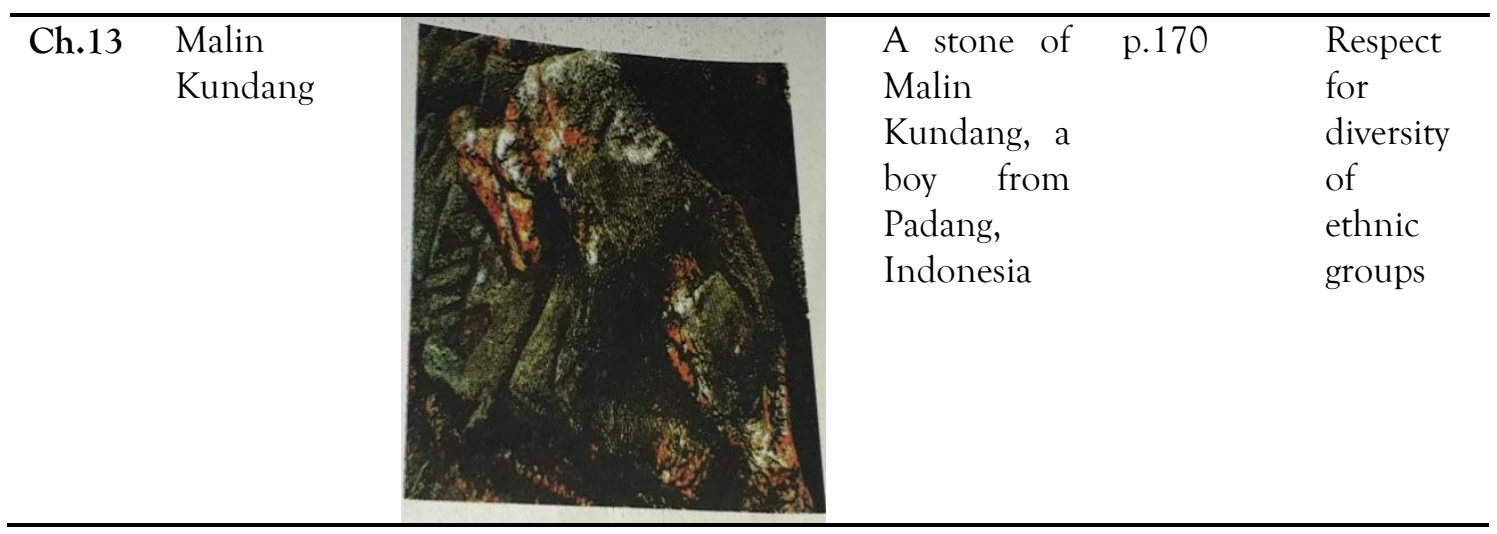

\section{A. Visual Representation of Cultural Values of the Narrative Texts}

The selected textbook represented visual representations of cultural values as listed in table 1 . Visual artifacts 1 (p.157), 2 (P.158), 3 (p.170), 4 (p.10) were textbook characters portraying female and male folklore characters with different physical characteristics (appearances). Picture 1 is an old male character wearing a kimono traditional clot from Japan. He has a white shot hair wearing a traditional hat. He has white skin and slanting eyes. Picture 2 is a young female cartoon character. She has black long hair and white skin. She wears Kimono and plays a traditional character doll from Japan. In this chapter, the author referred to a female character of Japanese folklore dressing up using Kimono (traditional Japanese cloth) and with brighter skin. In addition, the book writer attempted to tell the different characters between Japanese old women and young ones.

The next analysis focused on pictures from chapter 13 . The first picture on page 170 was depicting characters from Padang, Indonesia. There were three characters in which two of them were females and one was male. The man is Malin Kundang; he wears traditional Malay cloth from Padang so does the female figures. The male character has a moustache, a tall body, and short black hair. Besides, he has white skin. Further, the two females have white skin, one of the women is young but another is old. The second picture on page 170 was the picture of Malin Kundang's stone. This stone has magic for many people who live around. The color of the stone is dark grey with the flat on position. This picture has a deep history between a mother and her son. 
To sum up, the characters in the textbook represented sociocultural phenomena associated with Indonesians' lives. Japanese characters and Indonesian characters on the pictures represented attributes of particular ethnic groups, as well as diverse attributes of female traditional characters, were recreated from the sociocultural heterogeneity life of Indonesian society (ideology) transformed by the ELT authors in the textbook. Hence, the discourse of female characters in the textbook encouraged textbook readers and users and senior high school students to understand and appreciate the cultural diversity and accepting racial tolerance. This is a crucial vision that gives a strong foundation for the existence of Indonesia as a multi-ethnic with various histories and cultural backgrounds.

\section{B. The Objective of the Lesson related to Cultural Values of the Narrative Texts}

"Issumboshi" is one folklore from japan. The story was presented in chapter 12 and aimed at an ability to distinguish the social functions, the structure of the text, linguistic elements of narrative text by giving and asking information related to the folklore in using the context. Social function in folklore "Issumboshi" is to entertain the readers, to teach or inform the readers, to embody the writer's reflections on the experience, and to nourish and extend the reader's imagination.

In this chapter, the author described the moral values of folklores "Issumboshi" and "Malin Kundang". Two moral values are articulated from Issumboshi; a). It encouraged readers to be confident; b). Issumboshi could protect the princess although she has a tiny body. Meanwhile, the Maling Kundang story has moral values consisting of; a). love and honor towards elderlies; (b) respect the parents.

English for secondary level especially for senior high school cannot be separated from the compulsory topic such as narrative text. In this lesson, students are usually required to be able to tell a story whether it is fairy tales either in spoken or written form. Although "storytelling" is one of the components of spoken English, narrative text is more dominant taught in the form of writing emphasizing understanding the generic structure of a story, analyze the character, background, and the storyline narrative. 
The researchers valued the textbook positively especially the presentation of two narrative stories from Japan and Indonesia. Those are two kinds of folklores with two different cultural backgrounds and values. Thus, it could develop students' knowledge about another culture through learning narrative stories. However, Issumboshi, a Japanese old men character wore a traditional cloth with traditional hats and white hair while Malin Kundang showed Minangnese people wearing traditional clothes from Padang (West Sumatra) Indonesia. This is the main difference between the two stories in terms of clothes.

On the other hand, the researchers found not only the differences between both of the stories but also the similarities that everyone from small villages who has unlucky life will go to uptown for getting a better life. Both of the main characters (Issumboshi \& Malin Kundang) went to uptown to make their life better than before.

\section{CONCLUSION}

The present study examined the cultural values of narrative texts in the English textbook for tenth-grade students of senior high school and how those values might contribute to senior high school students related to cultural awareness. The findings revealed that at least three cultural values could be identified. For instance, respect for the right indigenous people, finding peace and nature and with all forms of life, and appreciation of cultural products. Although there are some other more cultural and multicultural topics in the English textbook for students grade tenth, but the researcher only investigated the cultural values in the narrative texts such as cultural materials and values from certain history and folklores from certain parts of the world.

In line with the globalization of English language teaching and learning, there has been a paradigm in how cultural values are taught in ESL/EFL (English as a second language/ English as a foreign language) contexts. The paradigm considers the enclosure of local English culture varieties and multicultural aspects as supporting the intercultural communicative competence. The present study displays how cultural values are described in the English textbook published by the government of Indonesia where English is positioned as a foreign language. The 
textbook represented a multicultural ideology by appreciating and respecting various cultures and traditions of different ethnic groups around the world.

The English teachers should consider the textbook as an essential part of teaching practices since the language itself and the cultures cannot be separated in multicultural classroom contexts. In line with this issue, the English teachers need to have an active role in selecting the appropriate textbook and the textbook contents as the representation of cultural materials by giving corrective feedback to the textbook authors. Finally, as the textbook shows and promotes cultural contents, moral and religious values while the instructional encourages tasks/activities in ELT classrooms, the textbook needs to be more closely examined in future research.

\section{REFERENCES}

Barfield, S. C., \& Uzarski, J. (2009). Integrating Indigenous Cultures into English Language Teaching. In English Teaching Forum (Vol. 47, pp. 29).

Creswell, J. W. (2012). Educational research: Planning, conducting, and evaluating quantitative and qualitative research (4th ed.). Boston, MA: Pearson.

Faris I. N. (2014). Cultural content analysis of an English textbook for Senior High School Grade Three in Cianjur, West Java. Journal of English and Education, 2(2), 14-25.

Fernandez, D. (2011). Survei Penggunaan Buku Teks Dari Penerit Swasta NonBSE. niversitas Muhammadiyah Prof. DR. Hamka.

Kenan R. S. (2003). Narrative fiction. Taylor \& Francis e-library.

Kim, S.-Y., \& Paek, J. (2015). An Analysis of Culture-Related Content in English Textbooks. Linguistic Research, 32(Special Edition), 83-104. https://doi.org/10.17250/khisli.32..201507.005 
72 Celt: A Journal of Culture, English Language Teaching $\mathbb{E}$ Literature, Volume 20, Number 1, June 2020, pp. 59 - 72

Lestari, L. A. (2010). Teaching English Culture along with the Language. Universitas Negeri Surabaya.

Linda G. \& Wignell P. M. (1994). Making sense of functional grammar an introductory workbook. Sydney: Antipodean Educational Enterprises.

Phillips, C. (2017). Characteristic of narrative text.

Rahmawati G. (2015). Textbooks as learning resources of students at the school library at three senior high schools, 5(1).

Ranjan R. (2018). Role of textbooks in language teaching and learning. In Retrieved May 7, 2019, from Role of Textbook in Language Teaching and Learning. Retrieved from https://www.rajeevelt.com/role-of-textbooklanguage-teaching-learning-educationist/rajeev-ranjam

Setyono, B., \& Widodo, H. P. (2019). The representation of multicultural values in the Indonesian Ministry of Education and Culture-Endorsed EFL textbook: a critical discourse analysis. Intercultural Education, 115.

Tang, Y. (2006). Beyond behavior: Goals of cultural learning in the second language classroom. The Modern Language Journal, 90(1), 86-99.

Taurus Y. Hamizi \& Munjiatun. (2015). Analisis nilai budaya dalam kumpulan cerita rakyat dari bintan karya B.M Syamsudsin sesuai karakter anak sekolah dasar. Riau: Universitas Riau.

Toolan, M. (2012). Narrative: A critical linguistic introduction. Taylor \& Francis.

Tüm, G., \& Uguz, S. (2014). An investigation on the cultural elements in a Turkish textbook for foreigners. Procedia-Social and Behavioral Sciences, 158, 356-363. 